OPEN ACCESS

Edited by: Agostino Merico, Leibniz Center for Tropical Marine Ecology, Germany

Reviewed by: Bernardo Maestrini Michigan State University, USA Edoardo Puglisi, Università Cattolica del Sacro Cuore

Italy

*Correspondence:

Catherine M. Yule catherine.yule@monash.edu

Specialty section:

This article was submitted to Biogeoscience,

a section of the journal Frontiers in Earth Science

Received: 03 December 2015 Accepted: 04 April 2016 Published: 19 April 2016

Citation: Yule CM, Lim YY and Lim TY (2016) Degradation of Tropical Malaysian Peatlands Decreases Levels of Phenolics in Soil and in Leaves of Macaranga pruinosa. Front. Earth Sci. 4:45 doi: 10.3389/feart.2016.00045

\section{Degradation of Tropical Malaysian Peatlands Decreases Levels of Phenolics in Soil and in Leaves of Macaranga pruinosa}

\author{
Catherine M. Yule *, Yau Yan Lim and Tse Yuen Lim \\ Tropical Medicine and Biology Multidisciplinary Platform, School of Science, Monash University, Petaling Jaya, Malaysia
}

Indo-Malaysian tropical peat swamp forests (PSF) sequester enormous stores of carbon in the form of phenolic compounds, particularly lignin as well as tannins. These phenolic compounds are crucial for ecosystem functioning in PSF through their inter-related roles in peat formation and plant defenses. Disturbance of PSF causes destruction of the peat substrate, but the specific impact of disturbance on phenolic compounds in peat and its associated vegetation has not previously been examined. A scale was developed to score peatland degradation based on the three major human impacts that affect tropical PSF-logging, drainage, and fire. The objectives of this study were to compare the amount of phenolic compounds in Macaranga pruinosa, a common PSF tree, and in the peat substrate along a gradient of peatland degradation from pristine peat swamp forest to cleared, drained, and burnt peatlands. We examined phenolic compounds in M. pruinosa and in peat and found that levels of total phenolic compounds and total tannins decrease in the leaves of M.pruinosa and also in the surface peat layers with an increase in peatland degradation. We conclude that waterlogged conditions preserve the concentration of phenolic compounds in peat, and that even PSF that has been previously logged but which has recovered a full canopy cover will have high levels of total phenolic content (TPC) in peat. High levels of TPC in peat and in the flora are vital for the inhibition of decomposition of organic matter and this is crucial for the accretion of peat and the sequestration of carbon. Thus regional PSF flourish despite the phenolic rich, toxic, waterlogged, nutrient poor, conditions, and reversal of such conditions is a sign of degradation.

Keywords: tropical peat swamp forests, phenolic compounds, lignin, tannin, peatland drainage, Macaranga pruinosa

\section{INTRODUCTION}

Indo-Malaysian tropical peat swamp forests (PSF) flourish on phenolic rich, waterlogged, acidic, nutrient poor layers of peat up to $25 \mathrm{~m}$ deep (Yule, 2010; Page et al., 2011). They contain one of the largest global pools of terrestrial organic carbon (11-14\% of global soil carbon: Page et al., 2011), mostly (up to 76\%) in the form of lignin-the major constituent of wood (Andriesse, 1988). Lignin is a polyphenolic compound which builds up under waterlogged peat swamp

Abbreviations: PSF, Peat swamp forest; TPC, Total phenolic content; TTC, Total tannin content. 
conditions because it is extremely resistant to degradation except by aerobic fungi, termites, and some bacteria. Peat soil is also high in other phenolic compounds such as tannins which give the peat water its characteristic black color. Phenolic compounds are crucial for ecosystem functioning in PSF through their interrelated roles in peat formation and plant defenses.

Phenolic compounds are extremely diverse (several thousand have been identified) and they occur universally in plants (Lattanzio et al., 2012). They are particularly varied in vascular plants where they form structural components (lignin), function in plant defense against herbivory and microbial pathogens (e.g., tannins, flavonoids), protect against UV radiation (e.g., phenylpropanoids) and confer color (e.g., anthocyanins; Lattanzio et al., 2012; Constabel et al., 2014). Their composition and distribution in plants vary in different parts of the plant, at different ages, and in response to environmental conditions (Lattanzio et al., 2012; Romani et al., 2014). Our previous study (Lim et al., 2014) revealed that the total phenolic contents of leaves of six species of Macaranga (Family Euphorbiaceae) were up to $67 \%$ higher in specimens collected from four Malaysian PSFs compared with samples of leaves of the same species from three dryland forests on mineral soils. We also observed this trend at the same sites for seven other PSF species; ferns-Drynaria sparsisora, Dipteris conjugata, and Stenoclaena palustris; trees-Campnosperma auriculatum and Campnosperma coriacium; and gingers-Boesenbergia sp. and Etlingera elatior (Lim, 2012). High levels of phenolic compounds in PSF plants can be attributed to the extreme conditions of acidity, low nutrients, and waterlogging of the PSF because plants invest in production of phenolics (as well as tough, leathery leaves) for defense against factors such as herbivory, microbial pathogens and UV rays in order to retain existing leaves for as long as possible rather than investing resources in growth of new leaves (Coley et al., 1985; Yule and Gomez, 2009; Cheynier et al., 2013; Lim et al., 2014). These phenolic compounds are referred to as secondary metabolites as they are not directly involved in growth, development, or reproduction and their concentration will vary depending on the plant's need for defense and capacity to produce the compounds.

These phenolic compounds are also the key to peat formation. Water soluble phenolics-especially tannins leach from senescent leaves as soon as they fall creating the acidic, black, waters of PSF. Such compounds can bind soil proteins and exoenzymes and also inhibit fungal respiration and nitrification (Constabel et al., 2014). Consequently the water of PSF inhibits microbial growth and so decomposition in tropical PSF is extremely retarded (further inhibited by the tough, toxic, phenolrich PSF leaves, and low oxygen conditions) resulting in exponential leaf litter decay rates of 0.0005 to 0.0040 days $^{-1}$ (Yule and Gomez, 2009; Ong et al., 2015). This is in strong contrast to most tropical rainforests where extremely rapid decomposition of leaf litter by microbes and invertebrates (leaf litter breakdown rates as fast as 0.03 days $^{-1}$; Bothwell et al., 2014) supports high productivity despite the impoverished mineral soils. Yule and Gomez (2009) found that fungi and bacteria grew abundantly on endemic PSF leaf litter in a PSF but the leaves barely decomposed after 1 year (irrespective of whether they were submerged in peat water or on top of hummocks); yet leaf litter from a common secondary forest species broke down rapidly (submerged and on top of hummocks), showing that it was intrinsic properties of the leaves that prevented decomposition rather than acidic, low oxygen conditions. Despite the waterlogging, conditions in PSF are not necessarily anaerobic-particularly at the surface where leaves fall and where water may be flowing, although the water table deep within the peat is anaerobic. There is growing evidence that the slow decomposition of PSF plant litter resulting from their toughness and toxic secondary phenolic compounds (Yule and Gomez, 2009) is actually an adaptation of many of the plants, particularly ones with large tough leaves such as dipterocarp trees, to recover nutrients from the leaves by allowing time for fine roots to penetrate the leaves before they decompose (Ong et al., 2015).

Decomposition of litter in PSF is also affected by the microhabitats within the swamps which have an uneven topography of hollows and pools lying between hummocks typically formed by the root masses around the base of large trees. Ong et al. (2015) showed that leaf litter submerged in PSF pools decomposed significantly more slowly than litter located on hummocks. Thus peat accretion in a pristine PSF is promoted by the waterlogged conditions and the uneven topography causing the formation of pools, together with the high levels of phenolic compounds in the peat and in the flora which inhibit microbial decomposition-but what happens to the production of phenolic compounds in the plants when PSF are disturbed and how might this influence peat accretion?

The tropical PSF of Indonesia and Malaysia have been undergoing rapid destruction since the 1980s due to drainage, logging, fire, and agricultural conversion-particularly to oil palm plantations (Koh et al., 2011; Miettinen et al., 2012; Goldstein, 2016). Prior to clearing, drainage canals are excavated to lower the water table resulting in enormous losses of particulate and dissolved carbon which have been stored in the peat, potentially for thousands of years (Moore et al., 2013). By 2010 about $84 \%$ of SE Asian peatlands (originally 25 million ha) had been drained (Hooijer et al., 2010). Drainage reverses the conditions that lead to peat accretion, resulting in oxidation which stimulates microbial respiration (causing decomposition of peat), compaction, subsidence, and drying of peat (Andriesse, 1988; Anshari et al., 2010; Yule, 2010; Nuri et al., 2011; Mezbahuddin et al., 2014). Phenolic compounds such as lignin in the peat become degraded due to exposure to air which further promotes peat decomposition (Feist and Hon, 1984). Peat subsidence can be as much as $1 \mathrm{~m} /$ year in deeply drained peats (Katase, 1993). Dry peat is highly flammable and unless the water table is raised, peat fires (which are seasonally set to clear PSF in Indonesia and Malaysia) can continue burning underground for years due to the huge lignin deposits. Regional peatland fires now occur every dry season and contribute to $90 \%$ of SE Asian trans-boundary haze (Varkkey, 2013; Goldstein, 2016). This haze contains globally detectable amounts of $\mathrm{CO}_{2}$ and other greenhouse gases (up to $3.1 \%$ of current global $\mathrm{CO} 2$ emissions from fossil fuel combustion: Page et al., 2002; Couwenberg et al., 2010; Hooijer et al., 2010) as well as health threatening, particulate, organic, and elemental carbons (Heil and Goldammer, 2001; Afroz et al., 2003; Goldstein, 2016). 
Disturbance of PSF clearly leads to destruction of the peat substrate-particularly due to exposure to air, but the specific impact of disturbance on phenolic compounds in peat and its associated vegetation has not previously been examined. Consequently the objectives of this study were to compare the amount of phenolic compounds in a common peatswamp tree, Macaranga pruinosa (Miq.) Müll.Arg. (Family Euphorbiaceae), and in the peat substrate along a gradient of peatland degradation from pristine peat swamp forest to cleared, drained and burnt peatlands. We hypothesized that levels of total phenolic compounds and total tannins would decrease in the leaves of $M$. pruinosa and also in the surface peat layers with an increase in peatland degradation, and we tested this hypothesis in the present study. We predict that this would cause the leaves to be more readily decomposed by microbes, and lower amounts of phenolic compounds would be available to leach from the leaves into the peat, so the water would become less acidic and toxic. This would result in an increase in rates of litter decomposition and hence decrease accretion of leaf litter in disturbed peatlands, however this prediction remains to be tested in a future study.

\section{MATERIALS AND METHODS}

\section{Study Sites}

Eight peatlands in Peninsular Malaysia were selected (Figure 1, Table 2): one pristine peat swamp forest (Pekan), two previously logged, recovering mixed species forests (North Selangor and Kuantan), one mono-species secondary forest (Kuala Langat), two drained and partially cleared peatlands (Kuantan and Sungai Raja Muda), and two highly degraded, cleared and completely drained peatlands (Kuantan and Sungai Raja Muda). Samples were collected from three different areas in each peatland $(=24$ sites). All four PSF were permanently waterlogged and the water table fluctuated seasonally, flooding the forest floor during the wet season. Pekan is the only unlogged PSF remaining in Peninsular Malaysia but is not fully protected so is presently under threat. At Kuantan, a freeway cut through a PSF with two cleared, degraded peatlands on one side (one almost totally drained) and an intact forest on the other.

A scale was developed to score peatland degradation based on the three major human impacts that affect tropical PSF-logging, drainage and fire (Table 1). This scale was developed following extensive experience by the authors working in Indo-Malaysian peatlands (e.g., Voglmayr and Yule, 2006; Wells and Yule, 2008; Yule and Gomez, 2009; Yule, 2010; Lim, 2012; Lim et al., 2014; Ong et al., 2014, 2015). Logging, drainage, and fire cause different impacts but they are interrelated in that initial drainage typically precedes logging, and unless a PSF is drained and cleared, fire is extremely rare and is limited in extent. The impacts of logging depend on whether it is clear felling or selective logging, and how long ago it occurred. Tropical PSF will generally recover well after selective logging as long as the natural water table is maintained as far as possible. Following selective logging, drains will typically fill in with peat, and vegetation will grow over them quite quickly unless they are re-excavated. Conversely, drainage which permanently lowers the water table will promote microbial breakdown of peat and will promote fires (typically lit to clear

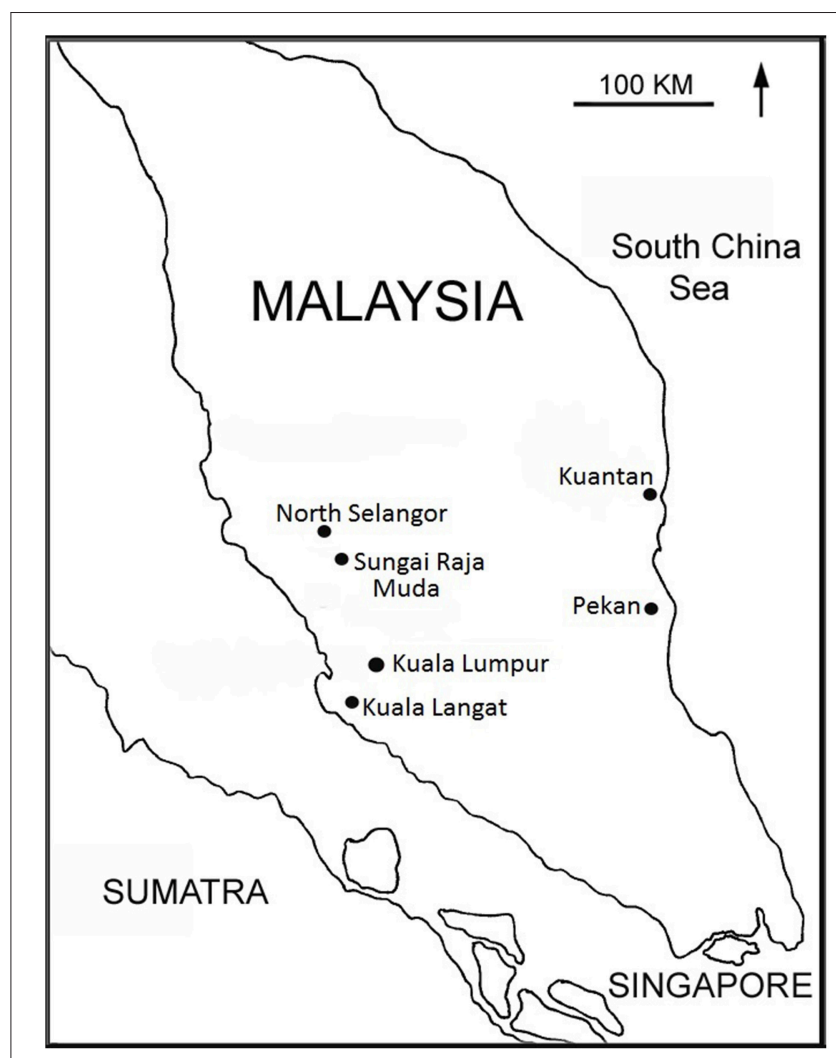

FIGURE 1 | Location of study sites in Peninsular Malaysia.

peatlands cheaply for agriculture). The greater the number of fires the worse the degradation and loss of the peat substrate, until eventually all the peat is burnt and the mineral soil beneath is exposed (as has happened with many peatlands in Malaysia and Indonesia). When peatlands are ranked using this scale the lower the score, the more similar the conditions are to the original forest with respect to forest cover, water table regime and peat quality, and vice versa. The scale closely reflects the scoring for peat quality developed by Von Post in 1922 (given in Tan et al., 2006) but instead of scoring the end products of peat degradation, it scores the causes.

A description of the eight peatlands is given in Table 2. They are ranked in order of increasing degradation from pristine to highly degraded based the scale given in Table 1 . The pristine forest at Pekan had never been logged and so it had emergent trees rising above the full canopy. It had no artificial drains except for some on the periphery far from the study sites-but these would not have affected the study sites which were located near Sungai Bebar, the river that naturally flows out of the swamp. Pekan had a naturally high water table and experienced seasonal flooding up to $1 \mathrm{~m}$ above the soil surface which prevented fires. The peat substrate was up to $15 \mathrm{~m}$ deep and comprised about $60 \%$ organic carbon (Table 3) made up of minimally decomposed peat with recognizable plant parts (particularly wood and roots) with a high level of moisture. All the other peatlands had been degraded by various amounts of logging and artificial drainage. The most degraded sites had been clearfelled, completely drained, and were 
TABLE 1 | Evaluation of peatland degradation based on logging, drainage and fire.

\begin{tabular}{ll}
\hline & Score \\
\hline LOGGING HISTORY & \\
No logging & 0 \\
Selective logging >20 years before & 0.5 \\
Selective logging 10-20 years before & 1 \\
Selective logging 5-10 years before & 1.5 \\
Selective logging <5 years before & 2 \\
Clear felled >20 years before & 1.5 \\
Clear felled 10-20 years before & 2 \\
Clear felled 5-10 years before & 2.5 \\
Clear felled <5 years before & 3 \\
DRAINAGE HISTORY & \\
No drains & 0 \\
Peripheral drains-but natural water table maintained with seasonal & 0.5 \\
flooding & \\
Peripheral and cross drains - but seasonal flooding still occurs & 1 \\
Extensive peripheral and cross drains - seasonal flooding prevented & 1.5 \\
Total drainage--water table no longer at or near surface & 2 \\
FIRE HISTORY & \\
No evidence of fires & 0 \\
At least one previous fire in recent times & 1 \\
Previous annual fires, reversed by flooding & 1.5 \\
Annual fires & 2 \\
\hline
\end{tabular}

subject to annual fires. Sungai Raja Muda-1 had previously been completely cleared and drained and had been subject to annual fires. Subsequently some of the drains were blocked enabling peat water to re-flood the area, preventing further fires.

\section{Sampling of Leaves and Peat}

At each of the 24 sites, sampling of leaves was undertaken every 60 days over a period of 180 days (except for Pekan where samples were only collected once due to difficulties in accessing the sites by boat). The study was conducted during the dry season and thus sampling on the east coast of Peninsular Malaysia (Pekan and Kuantan) was carried out 6 months after the west coast (North Selangor, Kuala Langat and Sungai Raja Muda) due to the different timing of the seasons. We sampled in the dry season to standardize the conditions because high rainfall during the wet season affects the hydrology of the PSF. For each peatland, 15 trees were selected and tagged in each site. Five mature leaves were then collected haphazardly from each plant on each sampling occasion (225 leaves per peatland, except for Pekan75 leaves) and transported to the laboratory in a cooler (20$25^{\circ} \mathrm{C}$ ). The samples were rinsed with distilled water, air dried and extracted within $24 \mathrm{~h}$. Three peat samples were collected from the surface of the peat, just below the leaf litter layer at each of the 24 sites on each sampling occasion (9 samples per site).

\section{Total Phenolic Content (TPC) of Leaves}

Extracts were prepared and analyzed as in Lim et al. (2014). $1 \mathrm{~g}$ of each of the fresh samples (in triplicate) was crushed mechanically into powder in liquid nitrogen. The crushed samples were extracted with $50 \mathrm{~mL}$ of $100 \%$ methanol by shaking the suspension on an orbital shaker for $1 \mathrm{~h}$. They were then filtered under suction and the extracts were stored at $-20^{\circ} \mathrm{C}$ until further use. A modified Folin-Ciocalteu assay (Kähkönen et al., 1999) was used to determine the total phenolic content (TPC). For TPC determination of the samples, $30 \mu \mathrm{L}$ of samples were introduced into microtitre plate wells followed by $150 \mu \mathrm{L}$ of Folin-Ciocalteu's reagent (10x dilution) and $120 \mu \mathrm{L}$ of sodium carbonate $(7.5 \% \mathrm{w} / \mathrm{v})$. The plate was allowed to stand for $10 \mathrm{~min}$ before absorbance at $765 \mathrm{~nm}$ was measured. TPC was expressed as gallic acid equivalent (GAE) in mg per $100 \mathrm{~g}$ material. The calibration equation was $\mathrm{y}=0.0079 \mathrm{x}-0.0023\left(r^{2}=0.9998\right)$ whereby $x$ represents concentration in $\mathrm{mg} / \mathrm{L}$ and $\mathrm{y}$ represents absorbance at $765 \mathrm{~nm}$.

\section{Total Tannin Content (TTC) of Leaves}

Determination of total tannin content was similar to that of TPC (See Makkar et al., 1993). Briefly, $0.3 \mathrm{~mL}$ of extract was mixed with $1.5 \mathrm{~mL}(1: 10)$ Folin-Ciocalteu's (F\&C) reagent and $1.2 \mathrm{~mL}$ of $20 \%(\mathrm{w} / \mathrm{v})$ sodium carbonate and the solution was left in the dark to stand for $30 \mathrm{~min}$. The absorbance measured at $765 \mathrm{~nm}$ allowed the determination of TPC in terms of tannic acid equivalent (TAE). In a separate tube, $100 \mathrm{mg}$ of PVPP (polyvinylpolypyrrolidone) was weighed and added to distilled water and extract $(1.0 \mathrm{~mL}$ each). The mixture was then vortexed at $4{ }^{\circ} \mathrm{C}$ for $15 \mathrm{~min}$ and centrifuged for $10 \mathrm{~min}$. at $3000 \mathrm{~g}$. The supernatant, which contained only simple phenolics as tannins were bound to PVPP, was collected. The phenolic content of the supernatant was then determined using the F\&C reagent. From the results, tannin content of the sample was calculated as: Total phenolics-non-tannin phenolics $=$ tannins (mg TAE/100g). TTC was expressed as tannic acid equivalent (TAE) in mg per $100 \mathrm{~g}$ of materials. The calibration equation was $\mathrm{y}=0.097 \mathrm{x}-$ $0.0012\left(R^{2}=0.998\right)$ whereby $\mathrm{x}$ represents concentration in $\mathrm{mg} / \mathrm{L}$ and y represents absorbance at $765 \mathrm{~nm}$. It was produced in our laboratory using tannic acid as standard. The standard equation (based on UV-Vis absorbance measurement) determined can then be used in different batches of measurements. The TTC: TPC ratio was determined by dividing the total phenolic values with the tannin values obtained previously. High molecular weight phenolics are represented by tannins and their derivatives (Pridham, 1964).

\section{Field Measurements}

At each site a soil corer was used to remove a $10 \mathrm{~cm}$ diameter core of peat up to $50 \mathrm{~cm}$ deep so that probes could be lowered into the water table. Dissolved oxygen (DO), temperature and $\mathrm{pH}$ of the water were measured using a Eutech Cyberscan PD650 meter. To measure substrate acidity, $10 \mathrm{~g}$ of the substrate was mixed with $50 \mathrm{~mL}$ of $5 \% \mathrm{CaCl}_{2}$ solution and shaken for $30 \mathrm{~min}$. The $\mathrm{pH}$ was then measured using a $\mathrm{pH}$ probe.

\section{Collection of Peat Samples}

Peat samples were collected with a soil corer from the surface at each site. Previous studies by Lim (2012) revealed that levels of phenolic compounds and nutrients were significantly higher at the surface, where newly senescent leaves fall, than in deeper peat 


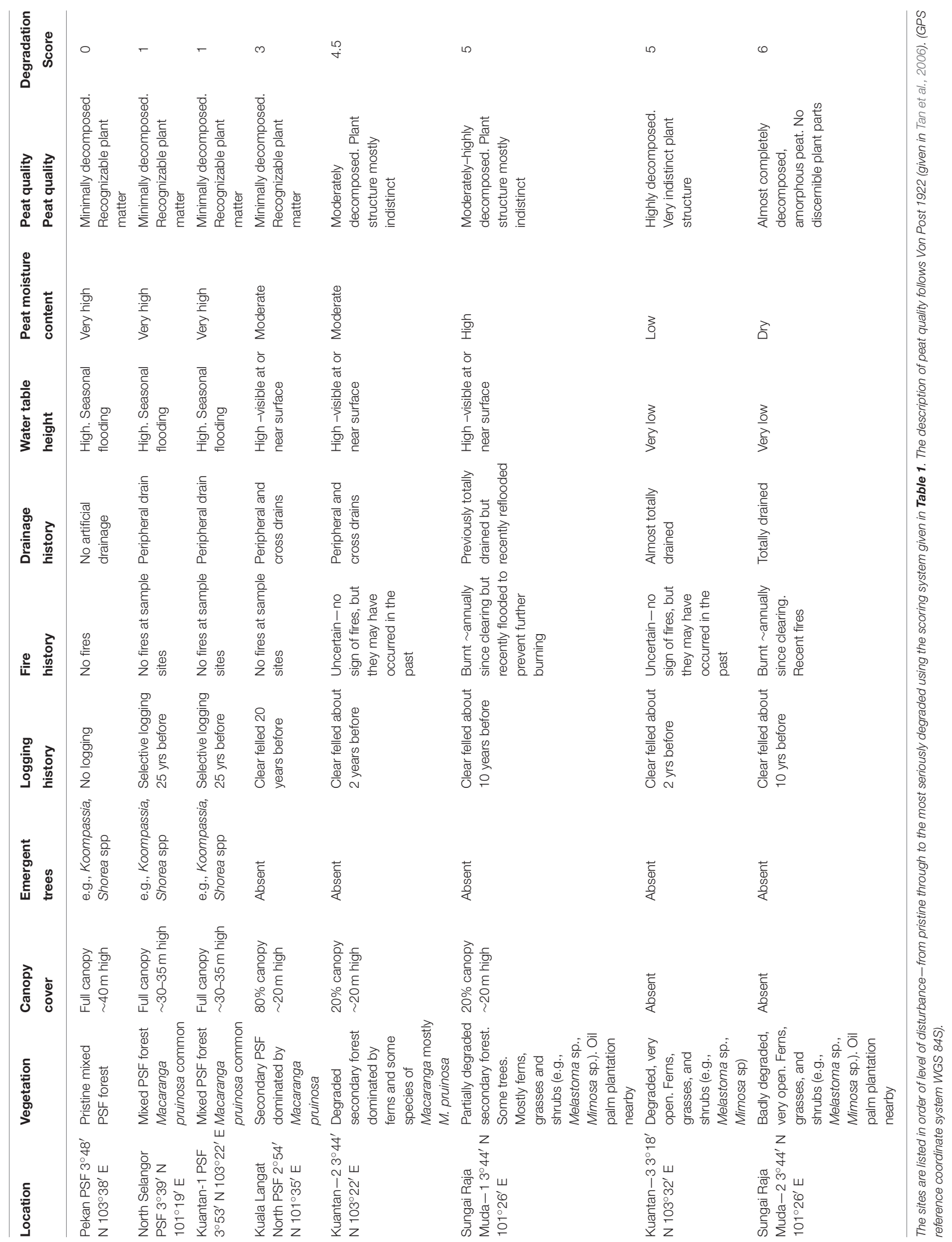


TABLE 3 | Chemical properties of peat water and surface peat at each site, ranked in order of increasing degradation level (mean values \pm 1 S.D; $n=3$ ).

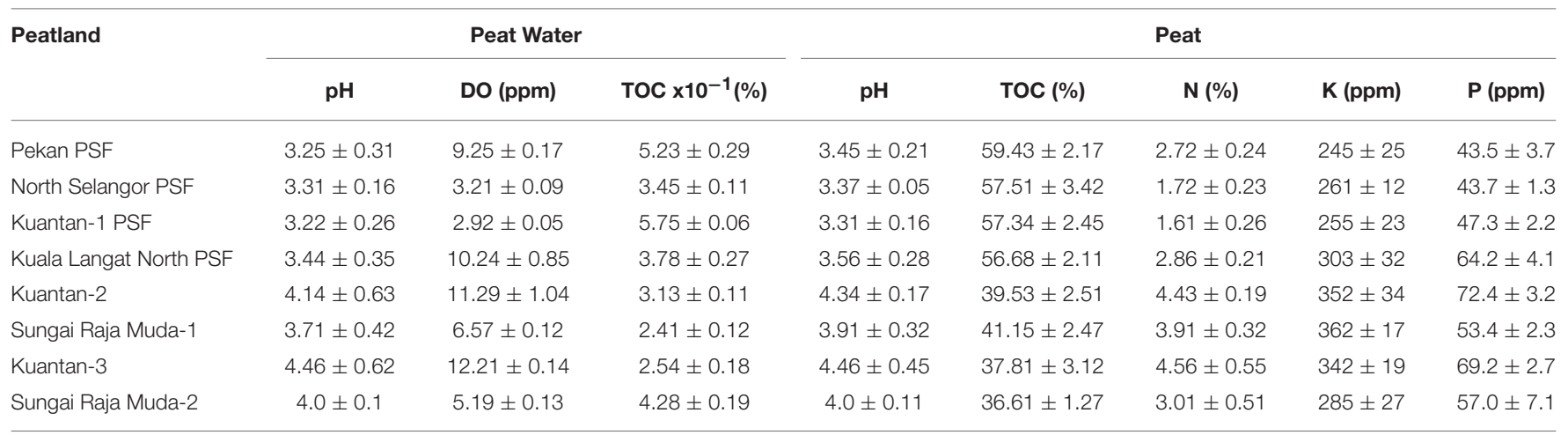

layers. For chemical assays of TPC and TTC, approximately $10 \mathrm{~g}$ of freeze dried peat was extracted with $100 \mathrm{~mL} 70 \%$ methanol by shaking the suspension continuously for $2 \mathrm{~h}$. It was then filtered and the solution was stored at $-20^{\circ} \mathrm{C}$. For nutrient and total organic carbon (TOC) analyses, approximately $200 \mathrm{~g}$ of soil was air dried and kept at room temperature $\left(25-27^{\circ} \mathrm{C}\right)$ and the analyses were outsourced to the Land Management Department of University Putra Malaysia using the combustion method.

\section{Total Phenolic Content of Peat}

Determination of TPC in peat extract was conducted using a similar method as described for leaves (see Section Total Phenolic Content (TPC) of Leaves).

\section{Total Tannin Content of Peat}

Determination of total tannin content of peat extract was conducted using a similar method as described for leaves (see Section Total Tannin Content (TTC) of Leaves).

\section{Statistical Analyses}

For comparison between phenolic contents of peat and leaf samples from the eight different peatlands, one way analysis of variance (ANOVA) were used and significant differences were identified using Tukey's HSD (honestly significant difference) test. For the analyses, the results for the five leaves collected from each tree were averaged to avoid pseudoreplication, thus degrees of freedom were determined by number of sites $x$ number of trees. Statistical analyses were conducted using SPSS version 16.0 and differences were considered to be significant at $p<0.05$.

\section{RESULTS}

\section{Chemical Characteristics of Surface Peat and Peat Water}

Table 3 summarizes the chemical properties in surface peat and peat water from each peatland. Soil and water $\mathrm{pH}$ were typical of regional PSF ( $\mathrm{pH} 2.9$ to $\mathrm{pH}$ 4) with the exception of the highly degraded Sungai Raja Muda peatlands which had higher $\mathrm{pH}$. DOC of peat water varied, but was highest in the least degraded sites-Pekan and Kuantan PSF. Oxygen levels varied greatly depending on water flow. PSF typically have pools between hummocks where water tends to be low in oxygen, and areas where water is flowing off the peat dome (sometimes in small streams and rivers) where oxygen levels will be higher. Artificial drains can also promote high flow rates and thus higher oxygen levels.

TOC values of peat decreased with increasing degradation. Forested peatlands had mean values of 56.7 to $59.4 \%$ (highest at the pristine Pekan PSF) which were higher compared to the degraded peatlands (all $<42 \%$ ) which were lowest at the most degraded peatland (36.6\%). These values show that the amount of undecomposed organic matter decreases as the surface peat is drained and oxidized. The values obtained from these peatlands were much higher compared to those of soil collected from a Malaysian hill dipterocarp forest (Pasoh Forest Reserve) which had mean TOC of $11.34 \pm 1.11 \%$ (Samy, 1999).

Nutrient levels were highest in the most disturbed peatlands at Kuantan 2, 3 and Sungai Raja Muda 1 and 2. Total nitrogen values were lower in the PSF (Pekan, North Selangor PSF, Kuantan-1 PSF and Kuala Langat PSF: 1.61-2.9\%) compared to the degraded peatlands (3.0-4.6\%). Total potassium values also showed a similar trend being lower in the PSF (Pekan, North Selangor PSF and Kuantan-1 PSF: 245-261 ppm) compared to the more degraded peatlands (285-362 ppm). A similar trend was observed for total phosphorus values which again were lower in Pekan (43.5 ppm), North Selangor PSF (43.7 ppm) and Kuantan-1 PSF (47.3 ppm). The remaining peatlands had values within a range of 53.4-72.4 ppm.

\section{Comparison of Phenolic Compounds in Leaves}

A significant decrease in quantities of phenolic compounds in the leaves of $M$. pruinosa was observed along a degradation gradient (Figure 2). Leaves of trees growing in the pristine Pekan PSF forest had almost double the mean concentrations of TPC compared to the trees in the most degraded peatlands at Kuantan and Sungai Raja Muda, and the mean levels of TPC at Pekan were 23-25\% higher than the previously selectively logged forests in North Selangor and Kuantan.

Similar results were seen for TTC values (Figure 3), whereby leaves of trees in Pekan PSF had significantly 


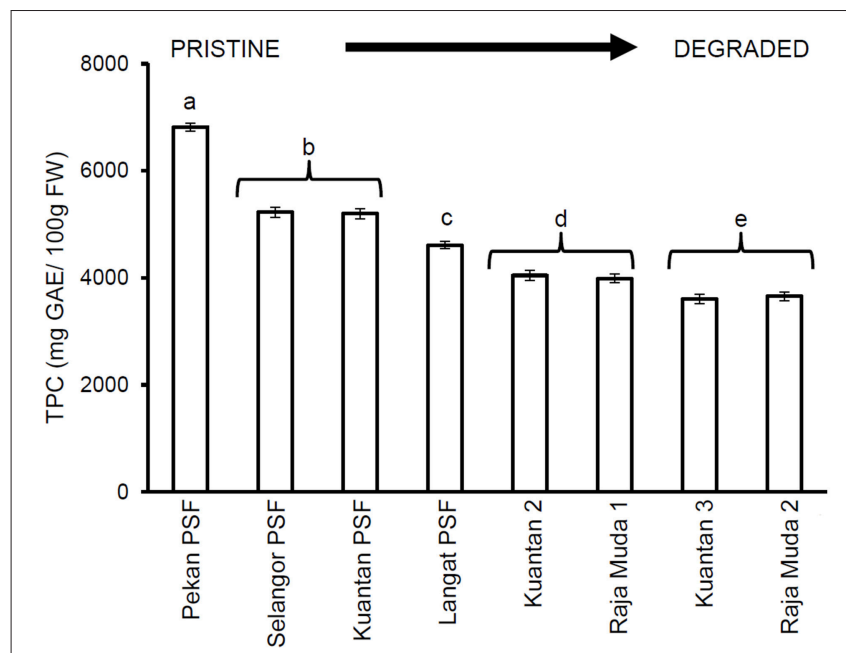

FIGURE 2 | Mean ( $\pm 1 S D$ ) total phenolic compounds in mature leaves of M. pruinosa at each peatland ( $n=\mathbf{4 5}$ except Pekan PSF, $n=15$ ). Values followed by the same letter (a-e) are not significantly different at $P<$ 0.05 as measured by the Tukey HSD test.

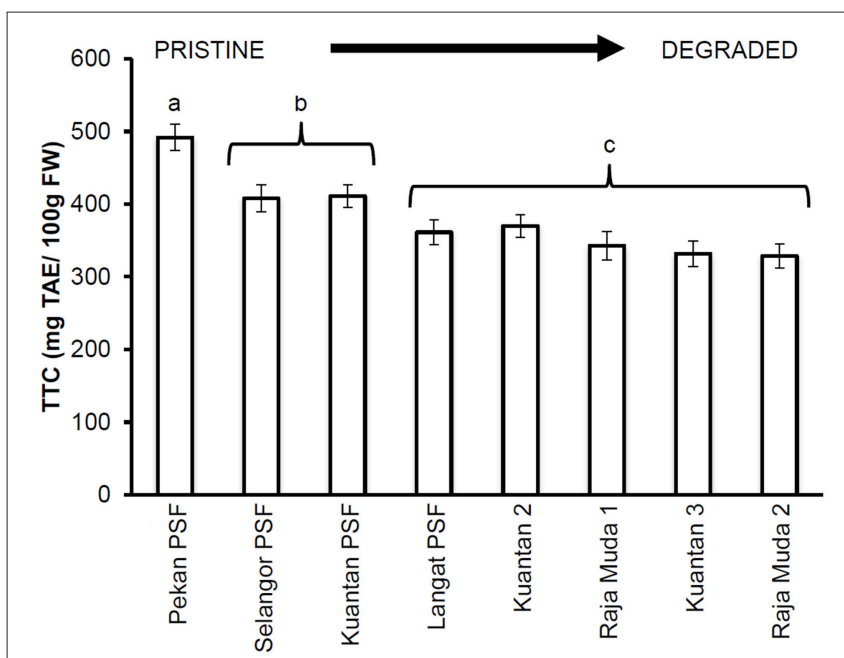

FIGURE 3 | Mean $( \pm 1 S D)$ total tannins in mature leaves of $M$. pruinosa at each peatland ( $n=\mathbf{4 5}$ except Pekan PSF, $n=\mathbf{1 5}$ ). Values followed by the same letter $(\mathrm{a}-\mathrm{C})$ are not significantly different at $P<0.05$ as measured by the Tukey HSD test.

higher tannin levels than the previously logged peatlands which had significantly higher tannin levels than the severely degraded peatlands (which all exhibited similar tannin levels). Figures 4, 5 depict the concentrations of TPC, and TTC in the surface peat which all followed a similar trend to the results for leaves of trees growing on the peat (Figures 2, 3). The values were similar in Pekan, North Selangor PSF, Kuantan-1 PSF and Kuala Langat PSF, and lower in Sungai Raja Muda -1 and Kuantan -2 . The lowest readings were observed in both Sungai Raja Muda -2 and Kuantan -3 .

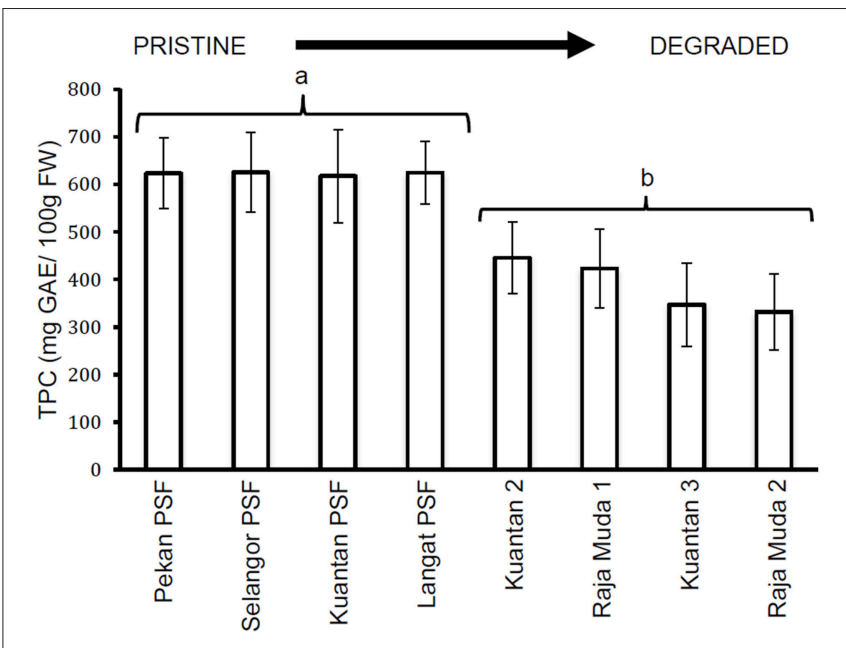

FIGURE 4 | Mean ( \pm 1 SD) total phenolic compounds in surface peat at each peatland ( $\boldsymbol{n}=\mathbf{2 7}$ except Pekan PSF, $\boldsymbol{n}=\mathbf{9}$ ). Values followed by the same letter ( $\mathrm{a}$ or $\mathrm{b}$ ) are not significantly different at $P<0.05$ as measured by the Tukey HSD test.

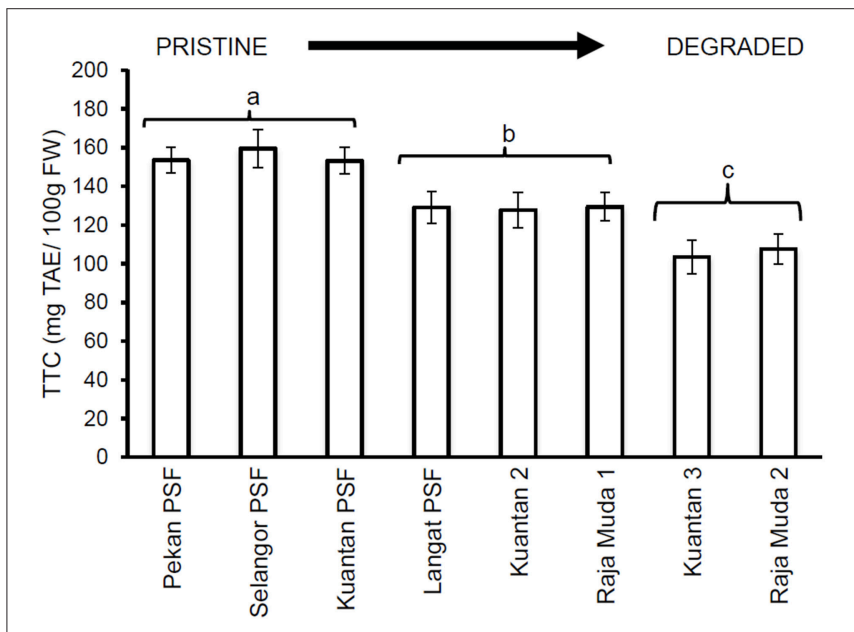

FIGURE 5 | Mean ( \pm 1 SD.) total tannins in surface peat at each peatland ( $n=27$ except Pekan PSF, $n=9$ ). Values followed by the same letter $(\mathrm{a}-\mathrm{C}$ ) are not significantly different at $P<0.05$ as measured by the Tukey HSD test.

\section{DISCUSSION}

Our hypothesis that levels of total phenolic compounds and total tannins would decrease in the leaves of $M$. pruinosa and also in the surface peat layers with an increase in peatland degradation was supported by the results (Figures 2-5), and supported our previous findings that leaves of $M$. pruinosa in PSF had higher TPC levels than the same species growing outside PSF (Lim et al., 2014). Phenolic compounds such as lignin in the peat become degraded due to exposure to air which promotes the microbial respiration and decomposition of the organic compounds and thus decreases levels of TPC and TTC. A mechanism to explain the higher levels of TPC in the leaves of PSF trees compared 
with plants growing on degraded peatlands is provided by our previous laboratory and field studies (Lim, 2012) which showed that $M$. pruinosa trees growing on acidic, waterlogged peat (where dissolved phenolics are present in high concentrations in the peat water) are capable of absorbing certain low molecular weight phenolic compounds which raises their levels of TPC.

Degraded peatlands are less acidic, lack a surface water table (and so are consequently aerobic), have lower levels of DOC and have higher levels of nutrients (Table 3) than PSF. Cleared PSF lack trees for replacement of phenols via litterfall, roots, and other plant debris, and exhibit chemical changes which: (1) promote microbial decomposition of phenolic compounds (especially lignin), (2) result in low availability of dissolved phenols for resorption by the trees. The substrates of undisturbed peat forests are more acidic, waterlogged, anaerobic, and low in nutrients which: (1) retard microbial decomposition of leaf litter, plant detritus and phenolic compounds in peat; (2) provide high levels of phenolic compounds leached from newly senescent leaves and peat for reabsorption by trees. Furthermore, as well as PSF conditions facilitating high TPC levels, the low nutrient conditions of PSF promote high TPC levels in the leaves as an adaptation to prevent herbivory and pathogen attack (Yule and Gomez, 2009; Lattanzio et al., 2012).

Pekan PSF was the only pristine forest sampled in this study. The leaves from this PSF contained the highest TPC and TTC values among all eight peatlands, but peat TPC and TTC values in Pekan PSF were similar to those of the previously logged PSFNorth Selangor, Kuantan -1 and Kuala Langat. The lower canopy heights of these logged forests and the greater abundance of secondary forest trees (particularly Macaranga species) in these forests compared to the pristine forest of Pekan demonstrates that these forests had not completely recovered from logging. The lower TPC and TTC of the leaves of M. pruinosa appears to reflect this lack of recovery. The remaining four peatlands, at Sungai Raja Muda and Kuantan, were no longer forested. They were separated on the basis that two had a visible water table, with water present in pools and they had more trees (Sungai Raja Muda 1 and Kuantan 2), while the others (Sungai Raja Muda 2 and Kuantan 3) did not have visible water and had very few trees. The vegetation in all four areas was similar, being dominated by ferns, grasses and shrubs. These results suggest that:

1) Waterlogged conditions preserve the concentration of phenolic compounds in peat.

\section{REFERENCES}

Afroz, R., Hassan, M. N., and Ibrahim, N. A. (2003). Review of air pollution and health impacts in Malaysia. Environ. Res. 92, 71-77. doi: 10.1016/S00139351(02)00059-2

Andriesse, J. P. (1988). Nature and Management of Tropical Peat Soils. Rome: Soil Resources, Management and Conservation Service, FAO Land and Water Development Division, Food and Agriculture Organization of the United Nations, Soils Bulletin.

Anshari, G. Z., Afifudin, M., Nuriman, M., Gusmayanti, E., Arianie, L., Susana, R., et al. (2010). Drainage and land use impacts on changes in selected peat
2) Even PSF that has been previously logged but which has recovered a full canopy cover will have high levels of TPC in peat because the vegetation of PSF contributes detritus which is high in TPC.

In a study of temperate forests in USA, Strakova et al. (2011) stated that "phenolics from plants degrade the habitat" and that they "may pose a serious threat to forest renewal" due to allelopathy (Dommain et al., 2014)-i.e., chemical inhibition, and furthermore they potentially create nutrient poor conditions. Other studies have also shown inhibitory effects of phenolic compounds on plant growth (e.g., Warren et al., 2012). Clearly this is not the case in Indo-Malaysian PSF where phenolics in the soil are key to maintenance of healthy PSF through retardation of decomposition and thus promotion of peat accretion. High levels of phenolics in the soil result from accumulation of leaves, roots, and other plant detritus that are resistant to microbial decomposition due to acidic, waterlogged conditions where the water has high levels of toxic phenols, as well as high levels of phenolic compounds in the plant detritus. PSF plants appear to be able to reabsorb low molecular weight phenolic acids and flavonoids under waterlogged acidic conditions (Lim, 2012) and so such conditions are beneficial to PSF plants rather than being stressful.

In conclusion, the highly diverse PSF with trees up to $70 \mathrm{~m}$ high (Yule, 2010) flourish because of the phenolic rich, toxic, waterlogged, nutrient poor, conditions, and reversal of such conditions is a sign of degradation. Drainage, logging, and fire will eventually result in complete destruction of peat, exposing the underlying mineral soil, and completely preventing rehabilitation of PSF.

\section{AUTHOR CONTRIBUTIONS}

Substantial contributions were achieved by all listed authors and were as follows: Conception and design of the work: TL, YL, CY. Acquisition of data: TL. Analysis and Interpretation of data: TL. Drafting and revising the work: TL, YL, CY.

\section{ACKNOWLEDGMENTS}

This work was part of TYL's PhD project funded by Monash University Malaysia.

properties and peat degradation in West Kalimantan Province, Indonesia. Biogeosciences 7, 3403-3419. doi: 10.5194/bg-7-3403-2010

Bothwell, L. D., Selmants, P. C., Giardina, C. P., and Litton, C. M. (2014). Leaf litter decomposition rates increase with rising mean annual temperature in Hawaiian tropical montane wet forests. PeerJ 2:e685. doi: 10.7717/peerj.685

Cheynier, V., Comte, G., Davies, K. M., Lattanzio, V., and Martens, S. (2013). Plant phenolics: recent advances on their biosynthesis, genetics, and ecophysiology. Plant Physiol. Biochem. 72, 1-20. doi: 10.1016/j.plaphy.2013.05.009

Coley, P. D., Bryant, J. P., and Chapin, F. S. (1985). Resource availability and plant antiherbivore defense. Science 230, 895-899. doi: 10.1126/science.230.47 28.895 
Constabel, P., Yoshida, K., and Walker, V. (2014). "Diverse ecological roles of plant tannins: plant defense and beyond," in Recent Advances in Polyphenol Research, Vol. 4, eds A. Romani, V. Lattanzio, and S. Quideau (Chichester: John Wiley \& Sons, Ltd), 115-142.

Couwenberg, J., Dommain, R., and Joosten, H. (2010). Greenhouse gas fluxes from tropical peatlands in south-east Asia. Glob. Chang. Biol. 16, 1715-1732. doi: 10.1111/j.1365-2486.2009.02016.x

Dommain, R., Couwenberg, J., Glaser, P. H., Joosten, H., and Suryadiputra, I. N. N. (2014). Carbon storage and release in Indonesian peatlands since the last deglaciation. Quat. Sci. Rev. 97, 1-32. doi: 10.1016/j.quascirev.2014.05.002

Feist, W. C., and Hon, D. N. S. (1984). "Chemistry of weathering and protection," in The Chemistry of Solid Wood, ed R. M. Rowell. (Washington, DC: American Chemical Society), 401-451.

Goldstein, J. E. (2016). Knowing the subterranean: Land grabbing, oil palm, and divergent expertise in Indonesia's peat soil. Environ. Plann. A 48, 754-770. doi: $10.1177 / 0308518 \times 15599787$

Heil, A., and Goldammer, J. (2001). Smoke-haze pollution: a review of the 1997 episode in Southeast Asia. Reg. Environ. Change 2, 24-37. doi: $10.1007 / \mathrm{s} 101130100021$

Hooijer, A., Page, S., Canadell, J. G., Silvius, M., Kwadijk, J., Wösten, H., et al. (2010). Current and future $\mathrm{CO}_{2}$ emissions from drained peatlands in Southeast Asia. Biogeosciences 7, 1505-1514. doi: 10.5194/bg-7-1505-2010

Kähkönen, M., Hopia, A., Vuorela, H., Rauha, J., Pihlaja, K., Kujala, T., et al. (1999). Antioxidant activity of plant extracts containing phenolic compounds. J. Agric. Food Chem. 47, 3954-3962. doi: 10.1021/jf9901461

Katase, T. (1993). Phenolic acids in tropical peats from Peninsular Malaysia: occurrence and possible diagenetic behavior. Soil Sci. 155, 155-165. doi: 10.1097/00010694-199303000-00001

Koh, L. P., Miettinen, J., Liew, S. C., and Ghazoul, J. (2011). Remotely sensed evidence of tropical peatland conversion to oil palm. Proc. Natl. Acad. Sci. U.S.A. 108, 5127-5132. doi: 10.1073/pnas.1018776108

Lattanzio, V., Cardinali, A., and Linsalata, V. (2012). "Plant phenolics: A biochemical and physiological perspective," in Recent Advances in Polyphenol Research. Vol. 3, eds V. Cheynier, P. Sarni-Manchado, and S. Quideau (Oxford: Wiley-Blackwell Publishing), 1-39.

Lim, T. Y. (2012). Environmental Effects Affecting Phenolic Production in Macaranga pruinosa in the Tropical Peat Swamp forest. Ph.D., Monash University Malaysia.

Lim, T. Y., Lim, Y. Y., and Yule, C. M. (2014). Bioactivity of leaves of Macaranga species in tropical peat swamp and non-peat swamp environments. J. Trop. Forest Sci. 26, 134-141.

Makkar, H. P. S., Blümmel, M., Borowy, N. K., and Becker, K. (1993). Gravimetric determination of tannins and their correlations with chemical and protein precipitation methods. J. Sci. Food Agric. 61, 161-165. doi: 10.1002/jsfa.2740610205

Mezbahuddin, M., Grant, R. F., and Hirano, T. (2014). Modelling effects of seasonal variation in water table depth on net ecosystem $\mathrm{CO}_{2}$ exchange of a tropical peatland. Biogeosciences 11, 577-599. doi: 10.5194/bg-11-577-2014

Miettinen, J., Shi, C., and Liew, S. C. (2012). Two decades of destruction in Southeast Asia's peat swamp forests. Front. Ecol. Environ. 10, 124-128. doi: $10.1890 / 100236$

Moore, S., Evans, C. D., Page, S. E., Garnett, M. H., Jones, T. G., Freeman, C., et al. (2013). Deep instability of deforested tropical peatlands revealed by fluvial organic carbon fluxes. Nature 493, 660-664. doi: 10.1038/nature11818

Nuri, A. S. M., Gandaseca, S., Ahmed, O. H., and Majid, N. M. A. (2011). Effect of tropical peat swamp forest clearing on soil carbon storage. Am. J. Agri. Biol. Sci. 6, 80-83. doi: 10.3844/ajabssp.2011.80.83
Ong, C. S. P., Juan, J. C., and Yule, C. M. (2015). Litterfall production and chemistry of Koompassia malaccensis and Shorea uliginosa in a tropical peat swamp forest: plant nutrient regulation and climate relationships. Trees 29, 527-537. doi: 10.1007/s00468-014-1130-y

Ong, K. S., Aw, Y. K., Gan, H. M., Yule, C. M., and Lee, S. M. (2014). Draft genome sequences of two antimicrobial-producing Burkholderia sp. Strains, MSh1 and MSh2, isolated from Malaysian tropical peat swamp forest soil. Genome Announc. 2:e01032-14. doi: 10.1128/genomea.01032-14

Page, S. E., Rieley, J. O., and Banks, C. J. (2011). Global and regional importance of the tropical peatland carbon pool. Glob. Chang. Biol. 17, 798-818. doi: 10.1111/j.1365-2486.2010.02279.x

Page, S. E., Siegert, F., Rieley, J. O., Boehm, H. V., Jaya, A., and Limin, S. (2002). The amount of carbon released from peat and forest fires in Indonesia during 1997. Nature 420, 61-65. doi: 10.1038/nature01131

Pridham, J. B. (1964). Low molecular weight phenolics in higher plants, 2. Annu. Rev. Plant Physiol. 16, 13-36. doi: 10.1146/annurev.pp.16.060165.000305

Romani, A., Lattanzio, V., and Quideau, S. (eds.) (2014). Recent Advances in Polyphenol Research, Vol. 4. Chichester: John Wiley \& Sons, Ltd.

Samy, J. (1999). Integrated Development Plan Study for Coastal Peat Land. Kuching: Sime publications.

Strakova, P., Niemi, R. M., Freeman, C., Peltoniemi, K., Toberman, H., Heiskanen, I., et al. (2011). Litter type affects the activity of aerobic decomposers in a boreal peatland more than site nutrient and water table regimes. Biogeosciences 8 , 2741-2755. doi: 10.5194/bg-8-2741-2011

Tan, T. S., Phoon, K. K., Hight, D. W., and Leroueil, S. (2006). "Characterisation and Engineering Properties of Natural Soils," in Proceedings of the Second International Workshop on Characterisation and Engineering Properties of Natural Soils (Boca Raton: CRC Press).

Varkkey, H. (2013). Patronage politics, plantation fires and transboundary haze. Environ. Hazards 12, 200-217. doi: 10.1080/17477891.2012.759524

Voglmayr, H., and Yule, C. M. (2006). Polyancora globosa gen. sp. nov., an aeroaquatic fungus from Malaysian peat swamp forests. Mycol. Res. 110 1242-1252. doi: 10.1016/j.mycres.2006.07.001

Warren, M. W., Kauffman, J. B., Murdiyarso, D., Anshari, G., Hergoualc'h, K., Kurnianto, S., et al. (2012). A cost-efficient method to assess carbon stocks in tropical peat soil. Biogeosciences 9, 4477-4485. doi: 10.5194/bg-9-44772012

Wells, A., and Yule, C. M. (2008). The caddisflies (Trichoptera) from a tropical peat swamp in Selangor, Peninsular Malaysia, including two new species. Aquat. Insects 30, 69-76. doi: 10.1080/01650420701687163

Yule, C. M. (2010). Loss of biodiversity and ecosystem functioning in Indo-Malayan peat swamp forests. Biodivers. Conserv. 19, 393-409. doi: 10.1007/s10531-008-9510-5

Yule, C. M., and Gomez, L. N. (2009). Leaf litter decomposition in a tropical peat swamp forest in Peninsular Malaysia. Wetlands Ecol. Manag. 17, 231-241. doi: 10.1007/s11273-008-9103-9

Conflict of Interest Statement: The authors declare that the research was conducted in the absence of any commercial or financial relationships that could be construed as a potential conflict of interest.

Copyright (c) 2016 Yule, Lim and Lim. This is an open-access article distributed under the terms of the Creative Commons Attribution License (CC BY). The use, distribution or reproduction in other forums is permitted, provided the original author(s) or licensor are credited and that the original publication in this journal is cited, in accordance with accepted academic practice. No use, distribution or reproduction is permitted which does not comply with these terms. 